\section{Croats protest that science minister is 'meddling' in MedllLS}

Federica Castellani, Munich

Croatian scientists are up in arms over possible government interference in plans for a world-class research institute on the Adriatic coast.

The Mediterranean Institute for Life Sciences (MedILS) would be established in Split, in the disused summer home of ex-Yugoslav leader Marshal Tito. The institute is the brainchild of Miroslav Radman, a Croatian biologist now at Necker Medical School in Paris and scientific adviser to Ivo Sanader, the Croatian prime minister.

But Croatia's research community has become increasingly concerned that Dragan Primorac, the science minister, is trying to stack the institute's advisory board with faculty members from the University of Split. Primorac founded the university's laboratory for clinical and forensic genetics in 1994 and ran it for nine years.

Radman has been threatening to withdraw from the institute in protest at what he sees as Primorac's meddling. "It was fundamental to the concept of MedILS that it should be under the leadership of an international scientific board, totally independent of local governments," he says.

And more than 1,000 Croatian researchers around the world have signed an Internet petition supporting Radman.

The project was endorsed by Ivica Racan, former prime minister of Croatia, in March 2003, but its future has been in doubt since he lost power to Sanader eight months later.

On 20 November, the Croatian government sought to end the uncertainty with the publication of a tender to complete the refurbishment of the building by next May. The government will pay for the renovation of the building and offer its use, rentfree, for $\mathbf{4 0}$ years. Radman will seek funds to support research and education there.

MedILS could boost Croatian research, says Kresimir Pavelic, head of molecular medicine at the Rudjer Boskovic Institute in Zagreb. "We are very provincial in our scientific outlook, and we need to grow internationally," he says. "That's why something like MedILS is so important to us."

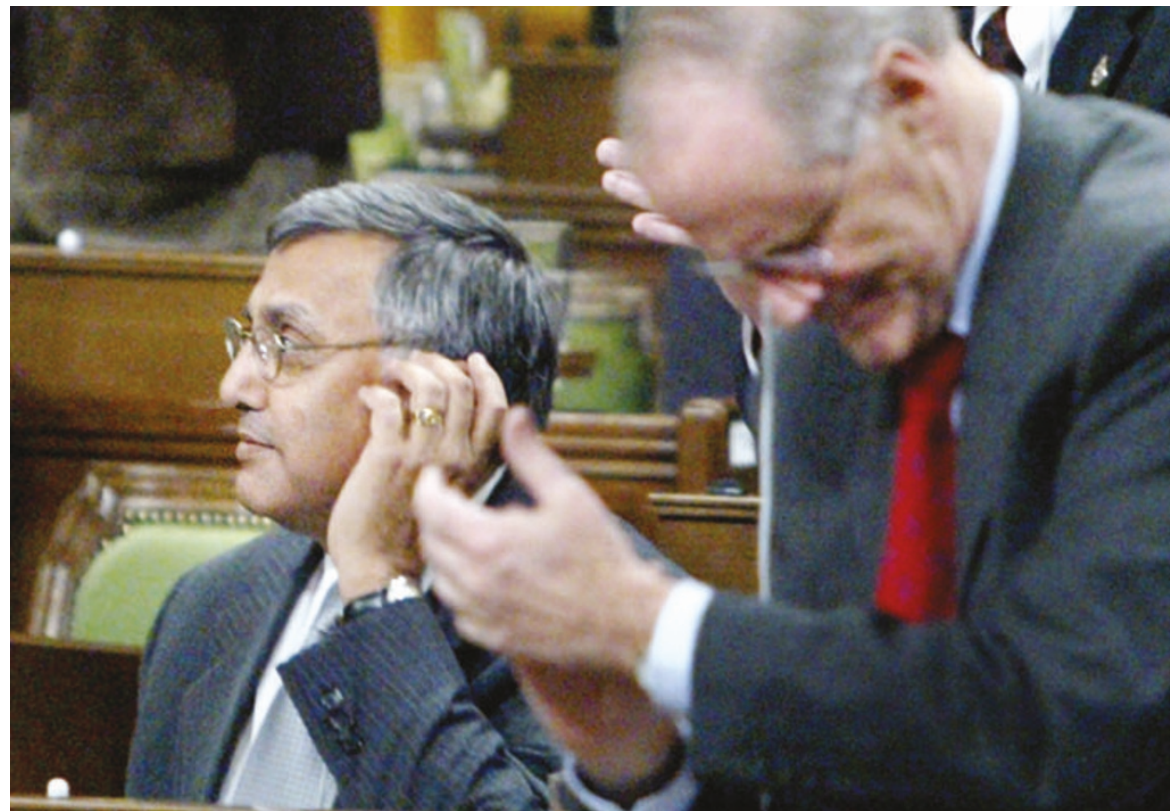

Applause for thought: Ujjal Dosanjh has promised compensation for Canadian hepatitis sufferers.

\title{
Canada pledges cash for more victims of blood-bank debacle
}

David Spurgeon, Montreal

The Canadian government has promised to broaden its compensation package for victims of a blood-transfusion scandal that hit the country in the 1990s. The change means that an extra 6,000 people who contracted hepatitis $C$ from Canada's national blood system should soon be eligible for financial awards.

"Compensation, quite frankly, should have been paid a long time ago," says Conservative opposition health critic Steven Fletcher. "I think the government has just given up trying to defend an indefensible position."

Problems with blood banks became apparent in several countries in the 1990s, with the realization that stocks had not been properly screened for viruses such as HIV and hepatitis, owing to a lack of knowledge and inadequate tests.

In 1998, when Jean Chrétien was prime minister, the Canadian government decided to compensate people who contracted hepatitis $\mathrm{C}$ from the national blood system - but only if they were infected between 1986 and 1990, when it said adequate tests were available but not used. This was despite an independent inquiry in 1997 that recommended compensation for everyone harmed by infected blood (see Nature 390, 432; 1997). The package, offered on condition that recipients would not sue, was for about Can $\$ 25,000$ (US $\$ 21,000$ ) per person.

Some provinces made money available for the 'forgotten victims' who were infected before 1986 or after 1990. But groups such as the Canadian Hemophilia Society campaigned for extended federal compensation, and some victims launched class-action suits.
The current Liberal government, elected in June, has now promised to open negotiations for those left out of the original Can\$1.1-billion compensation scheme. It says the new package will be sorted out with lawyers over the next few months.

Health minister Ujjal Dosanjh, who made the announcement last week, says the reason for the offer is that circumstances have changed. Some 10,000 people have so far applied for compensation - far fewer than the original government estimate of 22,000 - leaving about Can $\$ 869$ million of the original fund unclaimed. Treatment for hepatitis Chas also improved, says Dosanjh.

But observers say there are more political reasons for the decision. Canada's current prime minister, Paul Martin, is a bitter rival of Chrétien, and the new package acknowledges implicitly that Chrétien's government was wrong to limit compensation. Reform of the national healthcare system was a major plank in Martin's election campaign.

The Canadian Hemophilia Society welcomes the announcement by Dosanjh, but adds that the payments have not been been adjusted for inflation, and that a large number of those affected have already died.

Some $80 \%$ of those infected with hepatitis $\mathrm{C}$ initially show no symptoms. Infection eventually becomes chronic in $75-85 \%$ of cases, often causing liver disease and sometimes proving fatal. Victims' groups say that many are now dying or struggling financially because they cannot work and the drugs they need are not covered by medical plans. Drugs that bolster the immune system are effective in $50-75 \%$ of cases, depending on the type of infection. 